\title{
Механізми виникнення та хронізації нейропатичного болю при розсіяному склерозі в клінічних та експериментальних умовах
}

\author{
0.0. Нефьодов', О.І. Кальбус ${ }^{2}$ \\ 'Товариство з додатковою відповідальністю «ІНТЕРXIM», Дніпро, Україна \\ ${ }^{2}$ Дніпровський державний медичний університет, Дніпро, Україна
}

\begin{abstract}
Анотація. Розсіяний склероз (РС) - багатогранне, складне хронічне неврологічне захворювання, що призводить до рухових, сенсорних та когнітивних порушень. Симптоми РС непередбачувані та надзвичайно мінливі. Біль $€$ частим симптомом РС і проявляється ноцицептивним або нейропатичним болем (НБ) навіть на ранніх стадіях захворювання. НБ - один із найбільш виснажливих симптомів, що знижують якість життя та заважають повсякденній діяльності, особливо тому, що звичайні фармакотерапевтичні засоби адекватно не полегшують НБ. Незважаючи на здобутки, механізми, що лежать в основі НБ при РС, залишаються нез'ясованими. Більшість досліджень, що вивчали патофізіологію НБ, пов'язаного з РС, виконані на експериментальних тваринних моделях, які відтворюють деякі клінічні та нейропатологічні особливості РС. Експериментальний алергічний енцефаломієліт (ЕАЕ) — одна з найбільш вивчених і найчастіше використовуваних експериментальних моделей РС. Як і у пацієнтів з РС, у гризунів, уражених ЕАЕ, виявляють підвищену чутливість до болю, яку можна оцінити за допомогою тестів, що добре зарекомендували себе. Дослідження ЕАЕ надали цінну інформацію про патофізіологію НБ. Проте необхідні додаткові дослідження, щоб краще зрозуміти події, що призводять до виникнення та підтримання НБ, щоб визначити мішені, які можуть сприяти розробці ефективніших терапевтичних втручань. Мета цієї статті огляд декількох механізмів, пов'язаних із НБ при РС та EAE, шляхом узагальнення опублікованих літературних даних.
\end{abstract}

Ключові слова: розсіяний склероз, експериментальний алергічний енцефаломієліт, глія, нейрозапалення, нейропатичний біль.

\section{Вступ}

Розсіяний склероз (РС) - одне з найпоширеніших нейродегенеративних захворювань, що супроводжується хронічним запальним та демієлінізуючим процесами в центральній нервовій системі (ЦНС) [1, 2]. За оцінками, лише у США близько 1 млн осіб живуть із РС [3]. Найбільш схильні до захворювання особи молодого віку, початок захворювання припадає на вік 20-40 років. Поширеність патології у жінок утричі вища, ніж у чоловіків [4]. Навіть якщо у більшості пацієнтів спочатку відмічають рецидивуюче-ремітуючий PC (PP PC), захворювання протягом 10-20 років у кінцевому підсумку прогресує у вторинно-прогресуючу форму [5]. Основні симптоми включають слабкість кінцівок, стомлюваність, спастичність, сенсорні порушення, втрату координації, зниження когнітивних функцій, біль та параліч. Оскільки РС невиліковний, метою терапевтичних підходів $\epsilon$ уповільнення прогресування захворювання і зменшення вираженості симптомів для покращення якості життя пацієнтів [6].

Біль - частий симптом у хворих на РС, його відзначають у $28-$ $87 \%$ пацієнтів, з варіаціями часу виникнення та типу болю. Біль впливає як на фізичний, так і на емоційний стан пацієнтів і заважає виконанню більшості повсякденних дій, знижуючи розумову та фізичну працездатність, якість життя, призводячи до депресії та розвитку інших супутніх захворювань $[7,8]$.

Біль, пов'язаний із РС, можна розділити на 4 групи:

- м'язово-скелетний біль (болючі тонічні спазми; біль, вторинний щодо спастичності);

- центральний нейропатичний біль (НБ) (невралгія трійчастого нерва (НТН), синдром Лермітта);

- постійний центральний НБ;

- головний біль.

Незалежно від типу болю існує кореляція між болем та перебігом захворювання, його тривалістю та віком пацієнта [9]. М'язовоскелетний біль, особливо в нижніх кінцівках, зумовлений ектопічними імпульсами, що генеруються з рухових волокон внаслідок пошкодження аксонів та демієлінізації і найчастіше виникає вночі [10]. Головний біль та біль у попереку досить поширені у пацієнтів протягом усього захворювання [11, 12]. Важливо, що інші прояви болю виникають із прогресуванням РС. Спастичність та прогресу- юча слабкість порушують поставу та рухливість пацієнта, що призводить до остеопорозу та дисфункції сухожиль, зв'язок та/або суглобів, що спричиняє вторинний біль [10]. При цьому лікарські препарати, які зазвичай застосовують при симптоматиці РС, посилюють деякі з найбільш поширених типів болю [13]. Наприклад інтерферон- $\beta$ збільшує вираженість головного болю та мігрені [14].

\section{Механізми розвитку центральної}

\section{та периферичної форми НБ при РС}

Первинні сенсорні нейрони гангліїв задніх корінців сприймають шкідливі стимули через свої периферичні проєкції та передають інформацію про біль у задні роги спинного мозку (CM) через центральні проєкції. Центральні проєкції синапсу з сенсорними нейронами другого порядку та збуджувальними або гальмівними інтернейронами у задніх рогах також отримують проєкції із супраспінальних місць, що модулюють передачу болю. Ці сигнали інтегруються в задніх рогах, а потім передаються у різні ділянки головного мозку, де розвиваються сприйняття болю та афективні реакції на біль [15]. Поясна і острівцева кора, мигдалеподібне тіло і стовбур головного мозку входять до ділянок мозку, пов'язаних із больовими станами $[16,17]$.

НБ викликається пошкодженням або захворюванням, що уражує центральну або периферичну соматосенсорну систему, і має назву відповідно центрального або периферичного НБ $[18,19]$. Патофізіологічні зміни, пов'язані з НБ, включають підвищену збудливість нейронів у провідних шляхах болю. Нейрональна гіперзбудливість $\epsilon$ важливим механізмом, що лежить в основі підвищеної чутливості до болю при різних патологічних станах.

Центральна сенсибілізація проявляється підвищеною чутливістю до нешкідливих (алодинія) або шкідливих (гіперальгезія) подразників або спонтанним болем. Вона виникає при багатьох хронічних больових станах $[20,21]$, включаючи РС або його експериментальні моделі на тваринах [22], і не залежить від ураження периферичної нервової системи. Центральна сенсибілізація $\epsilon$ наслідком неадекватних змін у больових ланцюгах ЦНС та підвищеної збудливості нейронів, що частково пов'язано з підвищеною ефективністю синаптичної передачі через зниження гальмування [23]. Основні механізми, що лежать в основі центральної сенсибілізації, включають глутамат і глутаматні рецептори. Ефективність збудли- 
вих синапсів частково зростає внаслідок підвищеного вивільнення глутамату, порушення захоплення глутамату і надактивації рецепторів глутамату в нейронах задніх рогів, що беруть участь в обробці болю. Підвищена активність, експресія та трафік іонотропних рецепторів глутамату, таких як рецептори а-аміно-3-гідрокси-5-метил4-ізоксазолпропіонової кислоти (AMPA) та N-метил-D-аспартату (NMDA), відмічаються в сенсорних органах другого порядку нейронів задніх рогів [24, 25]. Метаботропні глутаматні рецептори (metabotropic glutamate receptors - mGluRs) також беруть участь у модуляції передачі болю, індукуючи вивільнення Са ${ }^{2+}$ із внутрішньоклітинних запасів, що, у свою чергу, активує кінази, включаючи фосфатидилінозитол-3 кіназу та мітогенактивовану протеїнкіназу. Активовані кінази фосфорилюють іонні канали та рецептори, що беруть участь у механізмах болю, змінюючи їх активність і призводячи до підвищення синаптичної ефективності [26]. Ці явища, поряд зі зниженням інгібуючої активності ГАМК-ергічних інтернейронів, та додаткові ефекти ненейрональних клітин посилюють збудливість нейронів. Зокрема, активована глія та інфільтруючі імунні клітини секретують проноцицептивні цитокіни, в тому числі фактор некрозу пухлини- $а$ та інтерлейкін-1 $\beta$, які посилюють збуджувальні та знижують гальмівні струми в нейронах задніх рогів. Реактивні астроцити пов'язані з гіперальгезією при патологічних станах [28]. Крім того, нисхідні норадренергічні та серотонінергічні проєкції до задніх рогів пригнічують або полегшують передачу болю [29]. Отже, викликані травмою або захворюванням відхилення у нисхідних шляхах болю модулюють хронічний біль (ХБ) [30]. Наприклад, у пацієнтів із РС часто відмічають ураження навколоводопровідної сірої речовини [31]. Остання $\epsilon$ важливим центром контролю модуляції та поширення болю по нисхідних шляхах із знеболювальним ефектом при його стимуляції [31]. Навпаки, ГАМК-ергічні клітини рострального вентромедіального мозку проєктуються в задніх рогах, де полегшують механічну ноцицепцію, інгібуючи спінальні ГАМК-ергічні інтернейрони [32]. Нарешті, важливо згадати, що супраспінальна глія також сприяє модуляції ХБ по нисхідних шляхах, зокрема через вивільнення розчинних медіаторів.

Периферична сенсибілізація проявляється посиленням реактивності первинно-чутливих нейронів у гангліях задніх корінців і зниженням больового порогу при пошкодженні або патології тканин, що ними іннервуються. Незалежний від стимулу спонтанний біль також $\epsilon$ одним із результатів периферичної сенсибілізації. В ураженій ділянці вивільняються множинні ефектори, у тому числі хемокіни, простагландини, пептид, споріднений з геном кальцитоніну, аденозинтрифосфат (АТФ), субстанція Р і фактор росту нервів (nerve growth factor - NGF) [33, 34]. Ці ефектори ініціюють молекулярний каскад, частково опосередкований рецепторами, пов'язаними з тирозинкіназою та G-білком. Протеїнкінази активуються та фосфорилюють іонні канали та рецептори на периферичних закінченнях ноцицепторів, тим самим змінюючи їх активність $[35,36]$. Крім того, одні й ті самі модулятори модифікують експресію, локалізацію та стабільність ноцицептивних іонних каналів та рецепторів. Загальними результатами цих змін $\epsilon$ підвищена активність ноцицепторів та зниження больового порогу [37].

\section{Клінічна патогномонічна симптоматика НБ при РС}

НБ значно поширений серед пацієнтів із РС і може мати кілька форм. НТН описують як короткочасне відчуття удару електричним струмом внаслідок подразнення трійчастого нерва, що насамперед впливає на різні ділянки обличчя. Біль може бути викликаний навіть легким подразненням обличчя. Напади можуть бути короткими (до 2 хв), часто виникають протягом дня (до 50 разів на день) [38]. Демієлінізація ділянки мосту, яка дотична до зони входу в корінець трійчастого нерва, і нейроваскулярна компресія корінця трійчастого нерва можуть відмічатися при РС і потенційно бути причиною НТН [38].

Подібно до НТН, симдром Лермітта описують як відчуття удару електричним струмом, пов'язане з рухом шиї, що поширюється вздовж спини і вниз по кінцівках [39]. Цей синдром не $\epsilon$ специфічним для РС і проявляється й при інших патологічних

станах, що включають компресію або ураження шийного відділу хребта. При РС синдром Лермітта може бути зумовлений демієлінізацією в дорсальних стовпах на шийному рівні [40].

Дизестетичний біль (у нижніх кінцівках) - найбільш поширена форма НБ, що описується як постійне печіння, поколювання та пульсація, хворобливі відчуття в ногах та ступнях. Незважаючи на те що специфічні механізми, які лежать в основі виникнення дизестетичного болю, не з'ясовані, передбачається, що ураження СМ можуть призводити до порушення передачі болю спиноталамічним трактом або розвиватися внаслідок дисфункції ГАМК-ергічних інтернейронів [41]. При РС у людей з дизестетичним болем у кінцівках при магнітно-резонансній томографії часто виявляють вогнища демієлінізації у шийному та грудному відділах СМ [40].

\section{Лікування НБ при РС}

Лікування НБ $\epsilon$ складним завданням, в основному через відносно низьку ефективність та побічні ефекти лікарських препаратів $[42,43]$. Трициклічні антидепресанти та інгібітори зворотного захоплення серотоніну/адреналіну застосовують як фармакотерапію 1-ї лінії. Протисудомні препарати, у тому числі габапентин та прегабалін, також вважають препаратами 1-ї лінії у лікуванні НБ при РС [42]. Хоча канабіноїди та опіоїди застосовували для полегшення НБ при РС, на сьогодні їх не розглядають як варіант стартової терапії $[44,45]$. Нейромодуляційна терапія стає все більш поширеною у клінічній практиці [46]. Хімічна та/або електрична стимуляція, а також гальмування мозку та підшкірної клітковини використовували для лікування різних хронічних больових станів [47]. Транскраніальна стимуляція [48], стимуляція поля периферичних нервів, черезшкірна спінальна стимуляція [49] також належать до методів лікування НБ при РС.

\section{Експериментальні моделі \\ Вивчення РС та НБ при РС}

EAE - одна з найбільш вивчених експериментальних моделей, що використовуються для вивчення різних патофізіологічних аспектів розвитку та перебігу РС, а також доклінічного вивчення засобів хворобомодифікуючої та симптоматичної терапії РC [50-53].

EAE може бути викликаний імунізацією сприйнятливих типів тварин мієліновими компонентами та енцефалітогенними пептидами або адаптивним перенесенням енцефалітогенних Т-клітин [50, 54]. Існують різні моделі ЕАЕ у різних видів експериментальних тварин, і вони імітують різні типи РС [55]. Початок, перебіг та тяжкість ЕАЕ відрізняються залежно від використовуваних антигену та ад'юванту, а також виду, лінії, статі та віку тварин. У межах одного і того самого виду та штаму сприйнятливість до EAE може бути різною залежно від внутрішніх факторів та факторів навколишнього середовища, таких як колонізація кишечнику та тип коменсальної флори - елементи, які складно контролювати [56-59].

Поряд із класичними формами EAE, індукованими сенсибілізацією до певного мієлінового білка, існують спонтанні та гуманізовані моделі EAE [60]. Серед цих моделей $\epsilon$ дві, які розроблені з використанням ліній трансгенних мишей: оптико-спинномозковий (експериментальна модель оптикомієліту Девіка) і спонтанний рецидивуюче-ремітуючий ЕАЕ (експериментальна модель РP РС). Ці моделі були корисні для розуміння ролі В-клітин та взаємодій В- та Т-клітин у патогенезі захворювання [61]. У мишей з оптико-спінальним ЕАЕ розвивається хронічне прогресуюче захворювання, яке уражує в першу чергу зоровий нерв і СМ. Неврологічні розлади, що спонтанно виникають, переважно нагадують оптикомієліт Девіка. Проте профіль транскриптома показав, що гени ризику РС людини входять до числа диференційно регульованих транскриптів, що підтверджує застосування цієї моделі у вивченні етіології PC [62]. У мишей, уражених спонтанним рецидивуюче-ремітуючим $\mathrm{EAE}$, захворювання розвивається з високою частотою і проявля$\epsilon$ ться унікальними клінічними ознаками з вираженими симптомами на початку (наприклад атаксія) та під час рецидиву (наприклад параліч задніх кінцівок). Особливо це виявляють у самок мишей. Клінічні симптоми подібні до уражень у відповідних ділянках ЦНС (наприклад ураження мозочка і стовбура мозку у мишей з атаксі- 
єю та ураження підшкірної клітковини у мишей з паралічем задніх кінцівок). Таким чином, спонтанний рецидивуюче-ремітуючий $\mathrm{EAE}$ $\epsilon$ корисною експериментальною моделлю у тварин для вивчення конкретних аспектів захворювання та методів лікування, оскільки імітує найчастішу форму РС [63]. Нейрозапалення, демієлінізуюче ураження, пошкодження аксонів, а також загибель олігодендроцитів і нейронів відмічаються при класичному EAE, при цьому найбільш ураженою ділянкою ЦНС $\in$ СМ. Такі гістопатологічні особливості подібні до нейропатології РС [64, 65].

Як і у випадку РС, у гризунів з ЕАЕ відмічається симптоматика болю [66-68]. Больова поведінка виявляється як при хронічно прогресуючому, так і при рецидивуюче-ремітуючому EAE [68]. Механічна та термічна алодинія зареєстрована при появі симптомів EAE та супроводжувалася дефіцитом когнітивної поведінки, про яку також повідомляли у пацієнтів із РС [69]. Подібно до РС поведінка під час болю та гіперчутливість відрізняються в різних моделях $\mathrm{EAE}$, що свідчить про неоднорідність захворювання та імітує різноманітність у пацієнтів з РС [70]. Нейрозапалення і тяжкість захворювання модулюють механічну гіперчутливість в моделі $\mathrm{EAE}$, індукованого MOG35-55. Подібно до каудально-рострального прогресування нейрозапальної реакції, що відмічається у СМ, висхідна сенсибілізація може розвиватися при ЕАЕ. Як морфологічні, так і функціональні зміни впливають на кіркові синапси, що беруть участь у центральній сенсибілізації та больовій гіперчутливості при ЕАЕ [71]. Підвищення інфільтрації імунних клітин, активація глії та вивільнення розчинних медіаторів запалення разом зі змінами рівнів глутамату та ГАМК, а також змінами у нейротрансмісії призводять до загального підвищення збудливості нейронів при ЕAE [72].

EAE корисний для розкриття декількох клітинних та молекулярних механізмів, що беруть участь у патогенезі РС, включаючи участь Т-клітин та інших інфільтруючих імунних клітин, а також роль, яку відіграють гуморальні компоненти імунної системи в нейродегенерації. Фактично у початкову фазу EAE головну роль відіграють Т-клітини. При активації на периферії Т-клітини продукують та секретують прозапальні цитокіни та долають гематоенцефалічний бар'єр. Проникнення Т-клітин у ЦНС опосередковується інтегринами та молекулами клітинної адгезії, що активуються. Потрапивши в ЦНС, ці Т-клітини повторно активуються антигенпрезентуючими клітинами [73]. Презентація антигенів мієлінового походження макрофагами Т-клітин, інфільтрація додаткових імунних клітин, включаючи макрофаги і В-клітини, а також активація глії призводять до складної та великої нейрозапальної реакції, що в кінцевому підсумку зумовлює демієлінізацію, втрату олігодендроцитів, а також нейронів [74]. Цитотоксичні ефекти цитокінів, активація білків комплементу, а також продукування і секреція активних форм кисню і азоту належать до молекулярних механізмів, що викликають пошкодження ЦНС [75]. Вільні радикали чинять серйозний пошкоджувальний вплив на метаболізм нейронів, цілісність мітохондрій та енергетичний баланс, що призводить до збільшення внутрішньоклітинного вмісту $\mathrm{Ca}^{2+} \mathrm{i}$, зрештою, до загибелі нейронів [76]. Через важливу роль, яку відіграє оксидативний стрес при РС, деякі з останніх методів лікування зосереджені на зменшенні вираженості шкідливих ефектів, що є результатом накопичення активних форм кисню та азоту [77]. Оксидативний стрес ушкоджує як нейрони, так й гліальні клітини, причому олігодендроцити $\epsilon$ найбільш чутливим типом клітин [78]. При активних ураженнях на ранніх стадіях РP РС окисне пошкодження торкається насамперед олігодендроцитів та мієліну [78]. Накопичення активних форм кисню та азоту в мітохондріях ставить під загрозу функцію олігодендроцитів та порушує диференціювання клітин - попередників олігодендроцитів. Це може бути механізмом, що лежить в основі порушення ремієлінізації [79], оскільки мітохондрії необхідні для біосинтезу ліпідів з утворенням мієліну [80]. Оксидативний стрес впливає на олігодендроцити та його попередники багатовекторно і, отже, може прямо чи опосередковано зумовлювати патофізіологію РС [81].

\section{Роль активованої глії та взаємодій глії з нейронами при НБ}

Після травми або захворювання глія зазнає морфофункціональних змін, переходячи в активний стан. Як зазначено вище, активація глії також відбувається при РС та ЕАЕ і вважається важливою детермінантою патології захворювання [82]. На додаток до мієлінового фагоцитозу та презентації антигену глія вивільняє прозапальні та проноцицептивні цитокіни, хемокіни, нейротрофічний фактор головного мозку (BDNF), активні форми кисню та аденозинтрифосфат (АТФ), що призводить як до нейротоксичності [83], так і до розвитку та підтримання НБ $[84,85]$. Активована глія також $\epsilon$ джерелом глутамату. Гомеостаз глутамату порушений при РС та ЕАЕ. Існують дані, що рівень глутамату у спинномозковій рідині пацієнтів із РС корелює з тяжкістю захворювання [86].

При РС відмічають підвищені рівні глутамату у сироватці крові та в активних ураженнях білої речовини. Оскільки глутамат та рецептори глутамату відіграють важливу роль у підвищеній збудливості сенсорних нейронів та сенсибілізації до болю, підвищене вивільнення глутамату глією потенційно зумовлює НБ при PC/EAE. Глутамат також може викликати ексайтотоксичність за рахунок активації іонотропних рецепторів, які беруть участь у нейродегенерації, що виникає при РС та ЕАЕ та інших розладах ЦНС [87]. На додаток до нейронів глія експресує іонотропні та метаботропні рецептори глутамату i, отже, їх функцію можна модулювати за допомогою прямої стимуляції глутаматом [88] (рисунок).

\section{Рисунок Молекулярні механізми, що лежать в основі больових реакцій при патологічних станах, включаючи ЕАЕ}

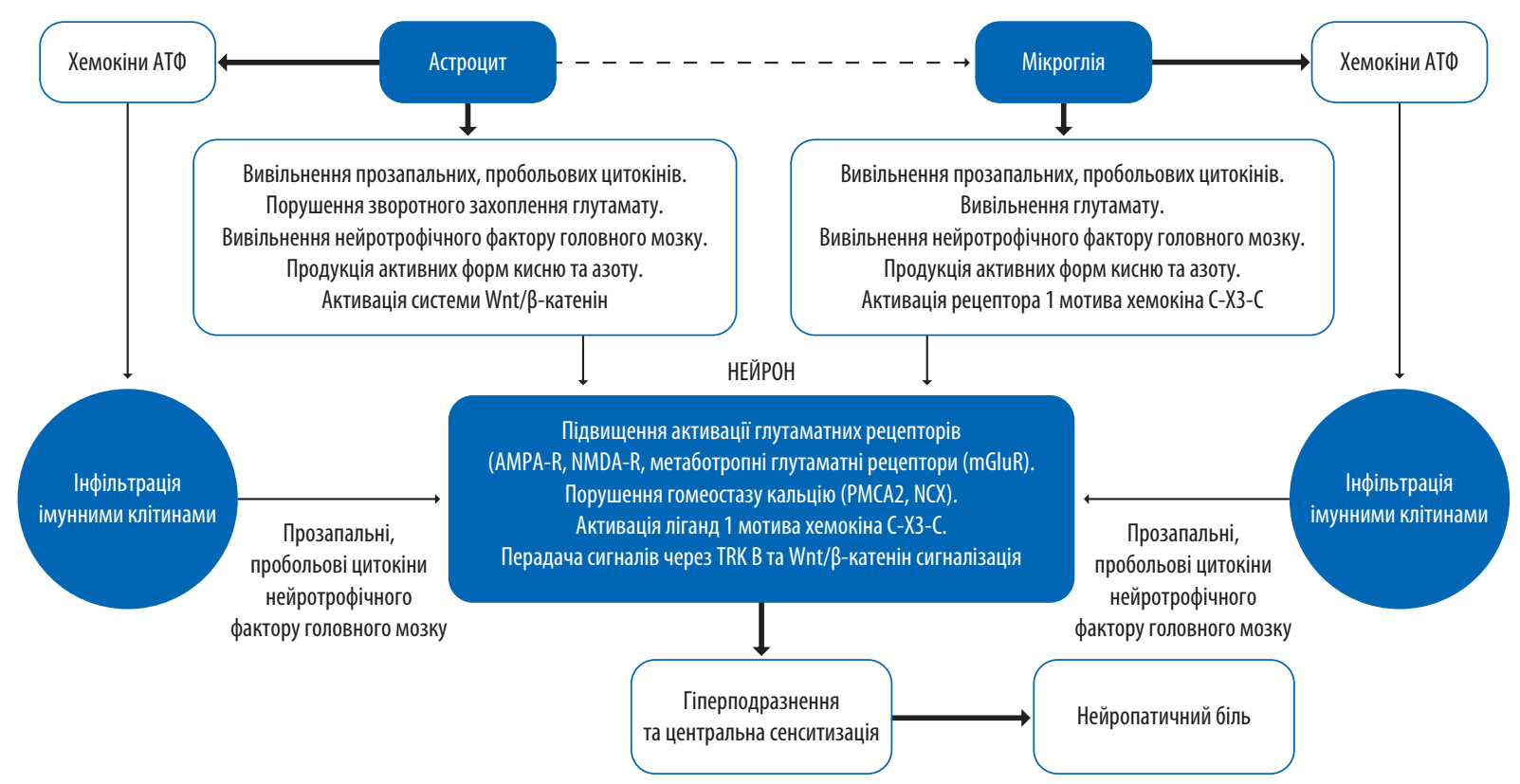




\section{Висновки}

Незважаючи на значну кількість експериментальних досліджень, інформація про механізми, що лежать в основі НБ, обмежена. Враховуючи високу частоту больових станів у осіб з РС, дуже важливо поглибити розуміння подій, що ведуть до виникнення та підтримання ХБ.

Виявлення специфічних аберантних механізмів та основних факторів, що беруть участь у розвитку та/або підтримці болю при PC/EAE, може значно змінити фармакологічний підхід до його лікування і тим самим покращити якість життя хворих.

\section{Список використаної літератури}

1. Simkins T.J., Duncan G.J., Bourdette D. (2021) Chronic demyelination and axonal degeneration in multiplesclerosis: pathogenesis and therapeuticimplications. Curr. Neurol. Neurosci. Rep., 21:26. D0I: 10.1007/s11910-021-01110-5

2. Nefodov 0., Dychko Ye., Zhytnii M., Chyrkin V. (2021) Experimental study of pharmacotherapy of neurological diseases for multiple sclerosis. Modernívěda, 5: 137-142.

3. Wallin M.T., Culpepper WJ., Campbell J.D. et al. (2019) The prevalence of MS in the United States: a population-based estimate using health claims data. Neurology, 92: e1029-e1040. D0I: 10.1212/ WNL.0000000000007035

4. Kingwell E.,MarriottJ.J., JettéN. etal. (2013) Incidence and prevalence of multiple sclerosis in Europe: a systematic review. BMC Neurol, 13: 128. D0l: 10.1186/1471-2377-13-128

5. CreeB.A.C.,AmoldD.L.,ChatawayJ.etal.(2021) Secondary progressivemultiplesclerosis:newinsights. Neurology, 97:378-388.

6. Kalia L.V., $0^{\prime}$ Connor P.W. (2005) Severity of chronic pain and its relationship to quality of life in multiple sclerosis. Mult. Scler, 11:322-327.D0l: 10.1191/1352458505ms11680a.

7. Нефьодов 0.0.,М'ясоєдЮ.П., СоломенкоМ.В. таін. (2021)Фармакологіяантиноцицепціїзаумов експериментального еквівалентурозсіяного склерозу. Вісн. пробл. біол. мед., 3(161): 131-136.

8. Marrie R.A., Reingold S., Cohen J. etal. (2015) The incidence and prevalence of psychiatric disorders in multiple sclerosis: a systematic review. Mult. Scler., 21:305-317. DOl: 10.1177/1352458514564487.

9. Solaro P.C., Brichetto L.G., Amato L.M. etal. (2004) The prevalence of pain in multiple sclerosis: a multicenter cross-sectional study. Neurology, 63: 919-921. D01: 10.1212/01. WNL.0000137047. 85868. D6.

10. Truini A., Barbanti P., Pozzilli C., (ruccu G. (2013) A mechanism-based classification of pain in multiple sclerosis. J Neurol., 260: 351-367. D0l: 10.1007/s00415-012-6579-2.

11. Kister l., Caminero A.B., Herbert J.,Lipton R.B. (2010) Tension-type headache and migraine in multiple sclerosis. Curr. Pain Headache Rep., 14: 441-448. D01: 10.1007/s11916-010-0143-5.

12. MassotC., Donze C., Guyot M.A., Leteneur S. (2021) Low back pain in patients with multiple sclerosis: a systematic review and the prevalence in a French multiple sclerosis population. Rev. Neurol., 177: 349-358. D01:10.1016/j.neurol.2020.07.018.

13. Kassirer M. (2000) Multiple sclerosis and pain: a medical focus. Int. J. MS Care, 2: 40-47. DOl: 10.7224/1537-2073-2.3.40.

14. Patti F., Nicoletti A., Pappalardo A. et al. (2012) Frequency and severity of headache is worsened by Interferon- $\beta$ therapy in patients with multiple sclerosis. Acta Neurol. Scand., 125: 91-95. D0I: 10.1111/j.1600-0404.2011.01532.x.

15. Browne T.J, Hughes D.I., Dayas C.V. et al. (2020) Projection neuron axon collaterals in the dorsal horn: placing a new player in spinal cord pain processing. Front. Physiol., 11: 560802. D0I: 10.3389/ fphys.2020.560802.

16. Dworkky-FriedZ., Faig C.A.,Vogel H.A. etal. (2021) Central amygdala inflammation drives pain hypersensitivity and attenuates morphine analgesia in experimental autoimmune encephalomyelitis. Pain, 10.1097/j.pain.0000000000002307.

17. Jiang Y.Y., Shao S., Zhang Y. et al. (2018) Neural pathways in medial septal cholinergic modulation of chronicpain: distinct contribution of the anterior cingulate cortex and ventral hippocampus. Pain, 159: 1550-1561.DOl: 10.1097/j.pain.0000000000001240.

18. Нефьодов 0.0.,М'ясоєдЮ.П., СоломенкоМ.В. таін. (2021) Експериментальневивченнялікування нейропатичногоболюзаумовмоделювання розсіяногосклерозу.Вісн.пробл. біол. мед., 4(162): $141-148$.

19. Smith E.S.J. (2018) Advances in understanding nociception and neuropathic pain. J. Neurol., 265: 231-238. D01: 10.1007/500415-017-8641-6.

20. Arendt-Nielsen L,,Morlion B.,PerrotS. etal. (2018) Assessment and manifestation of central sensitisation across different chronic pain conditions. Eur. J.Pain, 22:216-241.D01: 10.1002/ejp.1140.

21. Sanzarello I.,Merlini L., RosaM.A.etal.(2016) Central sensitization inchroniclowback pain:anarrative review. J. Back Musculoskelet. Rehabil., 29: 625-633. D01: 10.3233/BMR-160685.

22. Doolen S., Iannitti T., Donahue R.R. et al. (2018) Fingolimod reduces neuropathic pain behaviors in a mouse model of multiple sclerosis by a sphingosine-1 phosphate receptor 1-dependent inhibition of central sensitization in the dorsal horn. Pain, 159:224-238. D01: 10.1097/j.pain.0000000000001106.

23. vanden BroekeE.N. (2018) Central sensitization and pain hypersensitivity: some critical considerations. F1000Res., 7: 1325. DOI: 10.12688/f1000 research. 15956.2
24. Baron R., Hans G., Dickenson A.H. (2013) Peripheral input and its importance for central sensitization. Ann. Neurol., 74: 630-636. DOl: 10.1002/ana.24017.

25. Tao Y.X. (2012) AMPA receptor trafficking in inflammation-induced dorsal horn central sensitization. Neurosci. Bull., 28:111-120. D0l: 10.1007/s12264-012-1204-z.

26. Latremoliere A., WoolfC.J. (2009) Central sensitization: a generator of pain hypersensitivity by central neural plasticity. J. Pain, 10:895-926. 10.1016/j.jpain.2009.06.012.

27. KawasakiY., Zhang L., Cheng J.K., Ji R.R. (2008) Cytokine mechanisms of central sensitization: distinct and overlapping role of interleukin-1 beta, interleukin-6, and tumornecrosis factor-alpha in regulating synaptic and neuronal activity in the superficial spinal cord. J. Neurosci., 28:5189-5194.D0l: 10.1523/ JNEUROSCI.3338-07.2008.

28. Tang J., Bair M., Descalzi G. (2021) Reactive astrocytes: critical players in the development of chronic pain. Front. Psychiatr., 12: 682056. D0l: 10.3389/fpsyt.2021.682056

29. Zhuo M. (2017) Descending facilitation. Mol. Pain, 13: 1744806917699212. DOl: $10.1177 / 1744806917699212$.

30. Ossipov M.H., Morimura K., Porreca F. (2014) Descending pain modulation and chronification of pain. Curr. Opin. Support Palliat. Care, 8: 143-151. D01: 10.1097/SPC.0000000000000055.

31. Papadopoulou A., Naegelin Y., Weier K. et al. (2014) MRI characteristics of periaqueductal lesions in multiple sclerosis. Mult. Scler. Relat. Disord., 3:542-551. D01: 10.1016/j.msard.2014.01.001.

32. François A., Low S.A., Sypek E.I. et al. (2017) A brainstem-spinal cord inhibitory circuit for mechanical pain modulation byGABA and enkephalins. Neuron,93:822-839.D01:10.1016/j.neuron.2017.01.008.

33. Gautam M., Prasoon P., Kumar R. et al. (2016) Role of neurokinin type 1 receptor in nociception at the periphery and the spinal level in the rat. Spinal. Cord, 54: 172-182. D0l: 10.1038/sc.2015.206.

34. BarkerP.A.,MantyhP.,Arendt-Nielsen L. etal.(2020) Nervegrowth factorsignaling and its contribution to pain. J. Pain Res., 13: 1223-1241.D0I: 10.2147/JPR.S247472.

35. lyengarS.,Johnson K.W.,Ossipov M.H.,AuroraS.K. (2019) CGRP and the trigeminal system in migraine. Headache, 59:659-681.D0l: 10.1111/head.13529.

36. Salzer I., Ray S., Schicker K., Boehm S. (2019) Nociceptor signalling through ion channel regulation via GPCRs. Int. J. Mol. Sci., 20: 2488. D0l: 10.3390/ijms20102488.

37. Schaible H.G., Ebersberger A., Natura G. (2011) Update on peripheral mechanisms of pain: beyond prostaglandins and cytokines. Arthritis Res. Ther., 13:210. D0l: 10.1186/ar3305.

38. DiStefano G., Maarbjerg S., Truini A. (2019) Trigeminal neuralgia secondary to multiple sclerosis: from the clinical picture to the treatment options.J. HeadachePain, 20:20.D0l:10.1186/s10194-019-09690 .

39. Khare S., Seth D. (2015) Lhermitte's sign: the current status. Ann. Indian Acad. Neurol., 18: 154-156. DOl: 10.4103/0972-2327.150622

40. Al-ArajiA.H,OgerJ.(2005) Reappraisal oflhermitte's sign in multiplesclerosis. Mult.Scler., 11:398-402.

41. Khan N.,Smith M.T.(2014) Multiplesclerosis-inducedneuropathicpain: pharmacological management and pathophysiological insights from rodent EAE models. Inflammopharmacol., 22: 1-22.

42. Нефьодов 0.0.,М'ясоєдЮ.П.,Соломенко М.В.таін.(2021)Фармакологіяантиноцицепціїзаумов експериментального еквіваленту розсіяного склерозу. Вісн. пробл. біол. мед., 3(161): 131-136.

43. Solaro C., Messmer Uccelli M. (2010) Pharmacological management of pain in patients with multiple sclerosis. Drugs, 70: 1245-1254.

44. Cristino L., Bisogno T., Di Marzo V. (2020) Cannabinoids and the expanded endocannabinoid system in neurological disorders. Nat. Rev. Neurol., 16:9-29.

45. Murphy K.L., BetheaJ.R., FischerR. (2017) Neuropathic pain in multiplesclerosis - current therapeutic intervention and future treatment perspectives. In: Zagon I.S., McLaughlin P.J. (Eds.) Multiple Sclerosis: Perspectives in Treatment and Pathogenesis. Brisbane, QLD, 141 p.

46. Abboud H., Hill E., Siddiqui J. et al. (2017) Neuromodulation in multiple sclerosis. Mult. Scler., 23: 1663-1676.

47. Knotkova H., Hamani C., Sivanesan E. et al. (2021) Neuromodulation for chronic pain. Lancet, 397: 2111-2124.

48. Young J., Zoghi M., Khan F., Galea M.P. (2020) The effect of transcranial direct current stimulation on chronicneuropathic pain in patients with multiplesclerosis: randomized controlled trial. Pain Medicine, 21:3451-3457. D0l: 10.1093/pm/pnaa128

49. Klein J., Siepmann T., Schackert G. et al. (2020) Peripheral nerve field stimulation in medically refractory trigeminal neuralgia attributed to multiple sclerosis. J. Neurosurg., 134: 1244-1250.

50. Нефьодов 0.0., М'ясоєд Ю.П., Соломенко М.В. та ін. (2021) Ефективність моделювання експериментального алергічного енцефаломієліту як експериментальної моделі розсіяного склерозу.Укр. журн. мед. біол. спорту, 6(6): 57-65.

51. Steinman L., Zamvil S.S. (2006) How to successfully apply animal studies in experimental allergic encephalomyelitis to research on multiple sclerosis. Ann. Neurol., 60: 12-21.

52. Steinman L.,ZamvilS.S. (2005) Virtues and pitfalls of EAEfor the development of therapies for multiple sclerosis. Trends Immunol., 26: 565-571.

53. Constantinescu C.S., Faroogi N., O'Brien K., Gran B. (2011) Experimental autoimmune encephalomyelitis (EAE) as a model for multiple sclerosis. Br. J. Pharmacol., 164: 1079-1106.

54. Burrows D.J., McGown A., Jain S.A. et al. (2019) Animal models of multiple sclerosis: from rodents to zebrafish. Mult. Scler., 25: 306-324. 
55. Procaccini C., De Rosa V., Pucino V. etal. (2015) Animal models of MultipleSclerosis. Eur.J. Pharmacol., 759: 182-191.

56. Lebar R., Lubetzki C., Vincent C. et al. (1986) The M2 autoantigen of central nervous system myelin, a glycoprotein present in oligodendrocyte membrane. Clin. Exp. Immunol.,66: 423-434.

57. Hart B.A.T., Laman J.D., Bauer J. et al. (2004) Modelling of multiple sclerosis: lessons learned in a nonhuman primate. Lancet Neurol., 3:588-597.

58. Zamvil S.S.,Nelson P.A.,Mitchell D.J.etal. (1985) Encephalitogenic Tell clones specificformyelin basic protein. An unusual bias in antigen recognition. J. Exp. Med., 162: 2107-2124.

59. Yokote H., Miyake S., Croxford J.L. et al. (2008) Cell-dependent amelioration of a mouse model of multiple sclerosis by altering gut flora. Am. J. Pathol., 173: 1714-1723.

60. Ben-Nun A., Kaushansky N., Kawakami N. et al. (2014) From classic to spontaneous and humanized models of multiple sclerosis: impact on understanding pathogenesis and drug development. J. Autoimmun, 54: 33-50.

61. Molnarfi N., Schulze-TopphoffU., Weber M.S. et al. (2013) MHC class II-dependent B cell APC function is required for induction of CNS autoimmunityindependent of myelin-specific antibodies.J. Exp. Med., 210:2921-2937.

62. Faber H., Kurtoic D., Krishnamoorthy G. et al. (2020) Gene expression in spontaneous experimental autoimmune encephalomyelitisis linked to human multiplesclerosis riskgenes. Front. Immunol., 11:2165.

63. Pöllinger B.,Krishnamoorthy G.,BererK. etal.(2009) Spontaneous relapsing-remitting EAEintheSJL/J mouse: MOG-reactive transgenic T cells recruit endogenous MOG-specific B cells. J. Exp. Med., 206: 1303-1316.

64. Нефедов А.А.,Мамчур В.Й., ТвердохлебИ.В. (2016) Особенностиультраструктурыфронтальной коры и гиппокампа крыс в условиях экспериментального аллергического энцефаломиелита. Morphologia, 10(1):54-61.

65. Bjartmar C., Kidd G., MörkS. etal. (2000) Neurological disability correlates with spinal cord axonal loss and reduced $\mathrm{N}$-acetyl aspartate in chronic multiple sclerosis patients. Ann. Neurol., 48:893-901.

66. Takeuchi C., Yamagata K., Takemiya T. (2013) Variation in experimental autoimmune encephalomyelitis scores in a mouse model of multiple sclerosis. World J. Neurol.,3:56-61.

67. Migliore S., Ghazaryan A., Simonelli I. et al. (2017) Cognitive impairment in relapsing-remitting multiple sclerosis patients with very mild dinical disability. Behav. Neurol., 2017:7404289.

68. Lisi L., Navarra P., Cirocchi R. et al. (2012) Rapamycin reduces clinical signs and neuropathic pain in a chronic model of experimental autoimmune encephalomyelitis. J. Neuroimmunol., 243:43-51.

69. Damasceno A.,Damasceno B., Cendes. F.(2012) Brain cortical lesion load is related to cognitivedysfunction in multiplesclerosis patients. Neurology,78.D01:10.1212/WNL.78.1_MeetingAbstracts.P03.079

70. Lu J., Kurejova M., Wirotanseng L.N. et al. (2012) Pain in experimental autoimmune encephalitis: a comparative study between different mouse models. J. Neuroinflammation, 9:233.

71. Potter L.E., Paylor J.W., Suh J.S. et al. (2016) Altered excitatory-inhibitory balance within somatosensory cortex is associated with enhanced plasticity and pain sensitivity in a mouse model of multiple sclerosis. J. Neuroinflammation, 13: 142

72. Gao F., YinX.,Edden R.A.E.etal. (2018) Alteredhippocampal GABAandglutamatelevels and uncoupling from functional connectivity in multiple sclerosis. Hippocampus, 28: 813-823.

73. Fletcher J.M., Lalor S.J., Sweeney C.M. et al. (2010) T cells in multiple sclerosis and experimental autoimmune encephalomyelitis. Clin. Exp. Immunol., 162:1-11.

74. Gold R., Linington C., Lassmann H. (2006) Understanding pathogenesis and therapy of multiple sclerosis via animal models: 70 years of merits and culprits in experimental autoimmune encephalomyelitis research. Brain, 129(Pt. 8): 1953-1971.

75. Ortiz G.G., Pacheco-Moisés F.P., Bitzer-Quintero O.K. et al. (2013) Immunology and oxidative stress in multiple sclerosis: Clinical and basic approach. Clin. Dev. Immunol., 2013: 708659.

76. Chen X., Guo C., Kong J. (2012) Oxidative stress in neurodegenerative diseases. Neural. Regen. Res., 7: 376-385. DOl: 10.3969/.j.ssn.1673-5374.2012.05.009.

77. Witherick J., Wilkins A., Scolding N., Kemp K. (2010) Mechanisms of oxidative damage in multiple sclerosis and a cell therapy approach to treatment. Autoimmune Dis., 2011: 164608.

78. Lassmann H., van Horssen J. (2016) Oxidative stress and its impact on neurons and glia in multiple sclerosis lesions. Biochim. Biophys. Acta, 1862: 506-510.

\section{Відомості про авторів:}

Нефьодов Олександр Олександрович - доктор медичних наук, професор, начальник клінічного відділу товариства з додатковою відповідальністю «ННTEPXIM», Дніпро, Україна. scholar.google.com.ua/citations?user=kLObHKcAAAAJ\&hl=uk

Кальбус Олександр Іванович — доктор медичних наук, доцент, завідувач кафедри неврології Дніпровського державного медичного університету, Дніпро, Україна. scholar.google. com.ua/citations?user $=$ xosmIBIAAAAJ\&hl=uk\&oi=sra

Адреса для кореспонденції:

Кальбус Олександр Іванович

49044, Дніпро, вул. Моссаковського, 7, кв. 122

E-mail:kalbus.dp@gmail.com
79. Spaas.., vanVeggel L., Schepers M. etal.(2021) Oxidative stress and impaired oligodendrocyte precursor cell differentiation in neurological disorders. Cell Mol. Life Sci., 78: 4615-4637.

80. Meyer N., Rinholm J.E. (2021) Mitochondria in myelinating oligodendrocytes: slow and out of breath? Metabolites, 11:359.

81. AdamczykB., Adamezyk-Sowa M. (2016) New insights into the role of oxidative stress mechanisms in the pathophysiology and treatment of multiple sclerosis. Oxid. Med. Cell Longev., 2016: 1973834.

82. Zia S., Rawji K.S., Michaels N.J. et al. (2020) Microglia diversity in health and multiple sclerosis. Front. Immunol., 11:588021.

83. Robinson R.R., Dietz A.K., Maroof A.M. et al. (2019) The role of glial-neuronal metabolic cooperation in modulating progression of multiple sclerosis and neuropathic pain. Immunotherapy, 11:129-147.

84. Tsuda M., Inoue K. (2016) Neuron-microglia interaction by purinergic signaling in neuropathic pain following neurodegeneration. Neuropharmacology, 104: 76-81.

85. Pegoretti V., Swanson K.A., Bethea J.R. et al. (2020) Inflammation and oxidative stress in multiple sclerosis: consequences for therapy development. Oxid. Med. Cell Longev., 2020:7191080.

86. SarchielliP., Greco L.,Floridi A. etal. (2003) Excitatory amino acids and multiplesclerosis: evidencefrom cerebrospinal fluid. Arch. Neurol., 60: 1082-1088.

87. Rodriguez-ChavezV.,Moran J.,Molina-SalinasG. etal.(2021) Participation of glutamatergicionotropic receptors in excitotoxicity: the neuroprotective role of prolactin. Neuroscience, 461: 180-193.

88. PereiraV.,GoudetC. (2019) Emerging trends in pain modulation by metabotropicglutamatereceptors. Front Mol. Neurosci. 11:464.

\section{Mechanisms of occurrence and chronicity of neuropathic pain in multiple sclerosis in clinical and experimental conditions}

\subsection{Nefedov', O.I. Kalbus ${ }^{2}$}

${ }^{1}$ «INTERCHIM» Additional liability company, Dnipro, Ukraine

${ }^{2}$ Dnipro State Medical University, Dnipro, Ukraine

Abstract. Multiple sclerosis (MS) is a multifaceted, complex chronic neurological disease that leads to motor, sensory and cognitive impairment. The symptoms of MS are unpredictable and extremely variable. Pain is a frequent symptom of MS and is manifested by nociceptive or neuropathic pain (NP), even in the early stages of the disease. MS is one of the most debilitating symptoms that reduces the quality of life and interferes with daily activities, especially because conventional pharmacotherapeutic drugs do not adequately alleviate NP. Despite the achievements, the mechanisms underlying NP in MS remain unclear. Most studies examining the pathophysiology of NP associated with MS have been performed on experimental animal models that reproduce some of the clinical and neuropathological features of MS. Experimental allergic encephalomyelitis (EAE) is one of the most studied and most frequently used experimental models of MS. As in patients with MS, rodents affected by EAE have an increased sensitivity to pain, which can be assessed using well-proven tests. EAE studies have provided valuable information on the pathophysiology of NP. However, further research is needed to better understand the events that lead to and maintain NP in order to identify targets that may contribute to the development of more effective therapeutic interventions. The aim of this article is to review several mechanisms associated with NP in MS and EAE by summarizing published literature data.

Key words: multiple sclerosis, experimental allergic encephalomyelitis, glia, neuroinflammation, neuropathic pain.

\section{Information about the authors:}

Nefedov Oleksandr 0. - Doctor of Medical Sciences, Professor, «INTERCHIM» Additional liability company, Head of the Clinical Department, Dnipro, Ukraine. scholar.google.com.ua/citations?us er $=\mathrm{kLObHKCAAAAJ} \& \mathrm{hl}=u \mathrm{k}$

Kalbus Oleksandr I. - Doctor of Medical Sciences, Associate Professor, Dnipro State Medical University, Head of the Department of Neurology, Dnipro, Ukraine. scholar.google.com.ua/citations? user $=$ xosmIBIAAAAJ\&hl=uk\&oi=sra

Address for correspondence:

Oleksandr Kalbus

49044, Dnipro, Mossakovsky str., 7, apt. 122

E-mail:kalbus.dp@gmail.com 